\title{
Problematika guru dalam penerapan pendekatan saintifik pada pembelajaran PPKn
}

\author{
Manik Nur Haq ${ }^{\text {a, }}{ }^{*}$, Mukhamad Murdiono ${ }^{\text {b, } 2}$ \\ a, b, Prodi Pendidikan Pancasila dan Kewarganegaraan Pascasarjana Universitas Negeri Yogyakarta, \\ Sleman, Indonesia \\ ${ }^{1}$ manik.sukoco@gmail.com *; ${ }^{2}$ mukhamad_murdiono@uny.ac.id \\ *Korespondensi
}

\begin{tabular}{ll}
\hline \multicolumn{2}{l}{ Informasi Artikel } \\
\hline Sejarah artikel & \\
Diterima & $: 26-04-2019$ \\
Revisi & $: 16-09-2019$ \\
Dipublikasikan & $:$ 31-10-2019 \\
\hline
\end{tabular}

Kata kunci:

Problematika guru

Pendekatan saintifik

Saintifik inkuiri

Proses pembelajaran

PPkn

\begin{abstract}
ABSTRAK
Tujuan penelitian adalah untuk mengetahui masalah yang dialami guru dan upaya yang dapat dilakukan untuk mengatasi hambatan dalam penerapan pendekatan saintifik pada pembelajaran PPKn. Penelitian ini merupakan penelitian deskriptif kualitatif. Data dikumpulkan melalui wawancara, observasi, dan dokumentasi. Hasil penelitian menunjukkan bahwa masalah guru dalam penerapan pendekatan saintifik, antara lain: (1) keterbatasan kompetensi guru; (2) ketimpangan sarana dan prasarana; (3) keterbatasan waktu dan biaya; (4) minimnya kreativitas dan inovasi; (5) kurangnya antusiasme, motivasi, dan rasa ingin tahu peserta didik; (6) rendahnya kemampuan berpikir kritis, menyelesaikan masalah, dan mengambil keputusan; (7) kurangnya kemampuan komunikasi dan kolaborasi; (8) rendahnya minat baca; (9) kurangnya literasi informasi; (10) rendahnya literasi teknologi informasi dan komunikasi (TIK); (11) keterbatasan pelatihan dan sosialisasi mengenai perencanaan, proses, maupun evaluasi pembelajaran. Solusi yang dilakukan antara lain: (1) mengikuti seminar, pelatihan, dan kegiatan MGMP; (2) menjalin kerja sama dengan kepala sekolah, waka kurikulum, dan rekan sejawat; serta (3) membangun hubungan kemitraan antara guru dengan wali murid.

\section{ABSTRACT}

This study aimed to reveal the problems experienced by teachers and the efforts that can made to overcome obstacles in implementing the scientific approach toward civics and citizenship education. This study used qualitative descriptive method. Data collected through interviews, observation, and documentation. The results of the study showed that the teachers' problems in applying the scientific approach included: (1) the limitations of the teachers competency; (2) inequality of facilities and infrastructure; (3) time and cost limitations; (4) lack of creativity and innovation, (5) lack of enthusiasm, motivation and curiosity of the students; (6) lack of critical thinking, problem-solving, and decisionmaking skills; (7) lack of communication and collaboration skills; (8) low interest in reading; (9) lack of information literacy; (10) little information and communication technology literacy (ICT); (11) limited training and socialization regarding learning planning, process and evaluation. The solutions included: (1) attending seminars, training programs, and MGMP activities; (2) collaborating with the principal, the vice-principal, and colleagues, (3) and fostering collaboration between teachers and parents.
\end{abstract}

Keywords:

teachers' problems

scientific approach

scientific inquiry

learning process

civics and citizenship education

\section{Copyright () 2019 Manik Nur Haq dan Mukhamad Murdiono}

\section{Pendahuluan}

Kurikulum dalam sistem pendidikan bersifat dinamis serta harus dilakukan perubahan dan pengembangan, agar dapat memenuhi tantangan zaman. Memasuki abad ke-21, ada tiga tantangan utama yang dihadapi warga negara, yakni globalisasi ekonomi, perkembangan teknologi dan komunikasi, 
serta masalah populasi dan lingkungan (Cogan \& Derricott, 1998). Perubahan tren global tersebut merupakan alasan dilakukannya perubahan kebijakan pendidikan secara sistemis. Perubahan tersebut mencakup empat dimensi pendidikan kewarganegaraan, yaitu personal, sosial, temporal, dan spasial (Cogan \& Derricott, 1998).

Gelombang perubahan kurikulum untuk merespons perkembangan era global telah dimulai pada tahun 1960-an sebagai respons dari meningkatnya interdependensi yang menjadi karakter dari kehidupan kontemporer (Broome, 1973; Goodlad, 1967; Moyer, 1970). Salah satu kajian mengenai urgensi reformasi pendidikan dilakukan Shane \& Bernadine (1981) yang mengulas pentingnya penyesuaian konten kurikulum dengan dinamika perkembangan zaman. Pada akhir abad ke-20, rasional untuk melakukan perubahan kurikulum kian menguat sejalan dengan dampak globalisasi yang semakin meluas. Kebutuhan ini terkait dengan kerangka dan persepsi terhadap kompetensi abad ke-21 mendorong UNICEF untuk menerapkan dan mengkaji pendidikan global di kawasan Timur Tengah pada tahun 1995 dimana inisiatif "pendidikan untuk pembangunan" dipromosikan di negaranegara industri (Pike, 2008; Williams \& Cummings, 2015).

Selama ini reformasi yang dilakukan dalam bidang pendidikan hanya dipusatkan pada dua hal, yakni perluasan akses pendidikan dan peningkatan standar (Robinson, 2011). Pendidikan tidak pernah dibangun sebagai sebuah proses imparsial yang ditujukan untuk mengembangkan kemampuan alami peserta didik. Perubahan yang terjadi di era kesejagatan sangatlah cepat, dan tidak bisa diikuti oleh dunia pendidikan. Pendidikan ditantang bukan sekadar melakukan reformasi, namun juga bertransformasi (Robinson, 2011). Pengembangan imajinasi, kreativitas, dan inovasi bukan lagi sebuah opsi, namun menjadi kebutuhan yang mendesak. Berbagai tantangan di era global juga mendorong terjadinya transformasi nilai-nilai kompetensi yang dianggap berharga sepanjang sejarah, misalnya perubahan paradigma komunikasi dan kolaborasi. Kapabilitas interpersonal dalam berkomunikasi dan berkolaborasi kini telah menjadi salah satu prioritas dalam era industri (Balser, Grabau, Kniess, \& Page, 2017; Dede, 2010; Endersby, Phelps, \& Jenkins, 2017).

Pembelajaran merupakan proses pengembangan potensi dan pembangunan karakter peserta didik sebagai hasil dari sinergi antara pendidikan yang berlangsung di sekolah, keluarga, dan masyarakat. Pembelajaran pada Kurikulum 2013 menggunakan pendekatan saintifik. Dalam konteks pengembangan kurikulum, pendekatan ilmiah (saintifik) dimaknai sebagai sebuah pendekatan proses yang harus dilakukan dengan memenuhi nilai-nilai ilmiah. Namun, pendekatan saintifik juga mengacu pada teknik investigasi yang memuat langkah-langkah atau metode baku yang harus dilaksanakan secara berurutan (Kemendikbud, 2013, hal. 150). Penerapan metode ilmiah yang bersifat baku biasa dipakai dalam desain penelitian eksperimental klasik. Metode eksperimen klasik memang seringkali digunakan dalam buku teks. Masalahnya, tidak ada percobaan ilmiah yang secara konsisten menggunakan metode baku tersebut. Penelitian eksperimen juga tidak merepresentasikan penyelidikan ilmiah secara keseluruhan. Sayangnya, pemahaman yang keliru tersebut, justru dimasukkan sebagai bagian dari pengembangan kurikulum di sekolah-sekolah (Lederman, 2006).

Sejalan dengan pandangan peraturan mengenai kurikulum 2013, pembelajaran harus memberikan kesempatan kepada peserta didik untuk mengonstruksi pengetahuan sesuai dengan perkembangan kognisinya. Selanjutnya agar benar-benar memahami dan dapat menerapkan pengetahuan yang didapatkan, peserta didik perlu didorong untuk dapat memecahkan masalah, menemukan segala sesuatu untuk dirinya, dan berupaya keras mewujudkan ide-idenya.

Pemahaman guru mengenai esensi kurikulum sangatlah penting karena menentukan perubahan yang dilakukan untuk merespons perubahan kurikulum secara proporsional dan profesional (Muth'im, 
2014). Metode dan pendekatan pembelajaran yang digunakan oleh guru dalam pembelajaran juga mempengaruhi proses transformasi ilmu dari guru kepada siswa. Oleh karena itu guru dituntut untuk memiliki kreativitas dalam menggunakan metode dan pendekatan pembelajaran sehingga tujuan pendidikan dapat terpenuhi. Walau kurikulum 2013 telah menerapkan pembelajaran yang berpusat pada siswa, namun belum seluruh guru dalam satuan pendidikan mampu melaksanakan pembelajaran sesuai dengan amanat kurikulum. Ketidaksiapan pemerintah dan satuan pendidikan, keterbatasan kompetensi guru, ketimpangan sarana dan prasarana, keterbatasan waktu dan biaya, serta minimnya kreativitas dan inovasi masih menjadi penghambat dalam penerapan kurikulum 2013 (Muth'im, 2014; Rahmawati, Tairas, \& Nawangsari, 2018; Suyanto, 2017).

\section{Metode}

Penelitian ini memilih menggunakan pendekatan kualitatif sebab bertujuan untuk mengungkap dan memahami sesuatu di balik fenomena yang sama sekali belum diketahui, mendapatkan wawasan yang baru yang sedikit diketahui, serta untuk mengungkap makna yang terkandung dalam data yang telah dikumpulkan baik dari data observasi, wawancara, dan dokumentasi (Basrowi \& Suwandi, 2008). Untuk memperoleh data yang objektif, maka peneliti melakukan penelitian lapangan (field research) pada empat lokasi penelitian yaitu: SMPN 1 Grujugan, SMPN 1 Tapen, SMPN 2 Tenggarang, dan SMPN 1 Wonosari. Sumber data dan pengumpulan data dalam penelitian disesuaikan dengan tujuan dan fokus penelitian. Adapun waktu penelitian dilaksanakan pada bulan JuniSeptember 2017. Pengumpulan data dimulai dengan penentuan informan sesuai dengan kriteria sampel. Sebelum memulai wawancara, peneliti memperkenalkan diri terlebih dahulu dan menjelaskan maksud serta tujuan penelitian. Setelah informan memahami tujuan dari penelitian yang akan dilakukan, peneliti mendiskusikan waktu maupun tempat untuk mengadakan pertemuan.
Berdasarkan sumbernya, data yang digunakan dalam penelitian ini terdiri dari dua jenis, yaitu data primer dan data sekunder. Sumber data yang dimaksud adalah kepala sekolah, wakil kepala sekolah bidang kurikulum, guru mata pelajaran PPKn; dan peserta didik yang tersebar dalam empat lokasi penelitian. Data sekunder adalah berbagai teori dan informasi yang diperoleh tidak langsung dari sumbernya melainkan dari berbagai buku terkait dengan masalah yang diteliti, dokumen dan tulisan mengenai penerapan pendekatan saintifik, serta kelengkapan data seputar proses pembelajaran yang tersedia di sekolah.

\section{Hasil dan Pembahasan}

SMP Negeri 1 Grujugan terletak di pinggir jalan utama yang menghubungkan Kabupaten Jember dan Kabupaten Bondowoso. Sarana prasarana yang dimiliki cukup lengkap dan kondisinya baik. Lapangan sekolah cukup luas dan media pembelajaran yang disediakan, sudah cukup lengkap. SMP Negeri 1 Tapen terletak di jalan raya utama yang menghubungkan Kabupaten Bondowoso dengan Kabupaten Situbondo. Transportasi dari dan menuju sekolah cukup baik, termasuk kondisi sarana dan prasarana sekolah. Koneksi internet yang dimiliki sekolah masih terbatas, termasuk juga ketersediaan buku. SMP Negeri 2 Tenggarang, terletak di jalan raya yang menghubungkan antara Kabupaten Bondowoso dan Kabupaten Situbondo. Wilayah yang dimiliki sekolah tidak terlalu luas. Lima puluh persen bangunan sekolah dalam keadaan cukup baik. Sekolah masih memiliki keterbatasan dalam penyediaan buku. Namun, sekolah ini sudah memiliki laboratorium komputer. SMP Negeri 1 Wonosari terletak di Jalan Trunojoyo, Kecamatan Wonosari. Secara umum kondisi gedung masih cukup baik, namun ketersediaan buku dan alat penunjang masih cukup terbatas.

Hasil pengamatan yang dilakukan ternyata guru masih mengalami kesulitan dalam membuat perencanaan pembelajaran. Peraturan yang seringkali berubah membuat guru bingung. Beberapa guru yang diteliti masih menggunakan RPP lama. Perubahan 
kebijakan juga membuat guru yang tadinya sudah paham menjadi tidak paham dan harus belajar kembali dari awal. Hambatan lain yang ditemukan dalam penyusunan RPP adalah keterbatasan waktu yang dimiliki guru untuk membuat perencanaan pembelajaran.

Perubahan paradigma dari pembelajaran konvensional ke pembelajaran berbasis pencarian memang seringkali terhambat oleh dimensi mental (Fischer, Greiff, \& Funke, 2012; Johnson-Mardones, 2014). Dimensi mental adalah asumsi-asumsi yang terkadang membuat seseorang takut untuk melakukan perubahan. Berbagai asumsi dan ketakutan ini tidak hanya dialami oleh peserta namun juga oleh guru (Garcia \& Lewis, 2014; Jonnaert \& Therriault, 2013). Penciptaan kondisi lingkungan yang aman dan suportif diharapkan dapat mengatasi berbagai hambatan yang terkait dengan dimensi mental (Kisfalvi \& Oliver, 2015; Schmidt, 2018; Wanless, 2016) Melalui proses refleksi, setiap guru juga dimungkinkan untuk dapat saling menyemangati dan memupuk komitmen untuk dapat beradaptasi dengan segala perubahan (Clarkeburn \& Kettula, 2012; Kurniawan \& Toharudin, 2017; Mulyasa, 2013).

Kompetensi guru mempengaruhi kualitas perencanaan pembelajaran yang disusun (Tobiason, Heritage, Chang, Jones, \& Herman, 2014). Guru yang memiliki kompetensi personal, pedagogik, sosial, dan profesional akan mampu merancang pembelajaran sesuai dengan keadaan dan kebutuhan peserta didik, mengembangkan proses pembelajaran yang mampu mendidik karakter, meningkatkan kompetensi, serta menumbuhkan literasi peserta didik (Eggen \& Kauchak, 2016; Musingafi, Mhute, Zebron, \& Kaseke, 2015). Dalam rangka meningkatkan kualitas pendidikan, konsultasi dengan kepala sekolah dan rekan sejawat diperlukan untuk menghasilkan perencanaan pembelajaran yang berkualitas. Melalui proses pemberian umpan balik dan konsultasi secara berkelanjutan, pemahaman guru akan praktik pembelajaran yang baik dan relevan, dapat terus dikembangkan (Eggen \& Kauchak, 2016; Santrock, 2018).
Kegiatan belajar mengajar pada kurikulum 2013 dilakukan dengan mengacu pada pendekatan saintifik. Pendekatan ini menekankan pada penguasaan lima keterampilan proses berpikir yaitu: mengamati (observing), menanya (questioning), mencoba (experimenting), menyaji (networking), dan menalar (associating). Penerapan keterampilan proses dalam kegiatan belajar, sering disebut dengan saintifik inkuiri (scientific inquiry) atau pendekatan berbasis inkuiri (inquiry-based approach). Walaupun berkaitan dengan proses ilmiah, saintifik inkuiri adakalanya dihubungkan dengan pengembangan kemampuan proses seperti mengamati, menanya, mengklasifikasikan, mengukur, menganalisis, menginterpretasikan, memprediksi, dan mengambil kesimpulan. Saintifik inkuiri tak jarang dimaknai sebagai pendekatan sistematis yang digunakan oleh para ilmuwan dalam upaya menjawab pertanyaan penelitian (Lederman, 2006). Dalam praktiknya pendekatan berbasis inkuiri (inquiry-based approach) memiliki banyak variasi bentuk. Pendekatan yang mendeskripsikan sebagai pendekatan berbasis inkuiri, antara lain pembelajaran berbasis proyek, pembelajaran berbasis desain, dan pembelajaran berbasis masalah (Barron \& Darling-Hammond, 2008).

Dari hasil pengamatan, salah satu hambatan dalam penerapan pendekatan saintifik adalah kompetensi guru, yang tampak dari fenomena berikut yakni (1) guru belum memahami konsep pendekatan saintifik, (2) guru kesulitan dalam menyajikan materi agar mudah dipahami siswa, (3) guru mengalami kendala dalam mengidentifikasi kesalahpahaman siswa, (4) guru merasa kesulitan dalam melakukan manajemen kelas, mengatur waktu, dan memonitor pelaksanaan proses pembelajaran, dan (5) guru masih merasa kesulitan dalam mengorganisasikan proses belajar. Sebagian guru juga masih menggunakan pendekatan konvensional yang berpusat pada guru. Kegiatan pembelajaran PPKn seringkali dilakukan dengan membaca buku teks sehingga siswa kurang termotivasi. Selain itu tidak seluruh guru yang diteliti rajin memberikan pertanyaan-pertanyaan yang 
mendorong siswa untuk dapat memberikan respons serta tanggapan-tanggapan kreatif.

Penjelasan yang menarik dan sesuai dengan konteks peserta didik diharapkan dapat membantu mereka untuk dapat berpartisipasi dalam aspek menanya. Sayangnya penjelasan atau pendahuluan yang dilakukan oleh guru terkadang kurang menarik, tidak sesuai konteks, dan tidak mengulas pokok permasalahan sehingga tidak merangsang siswa untuk bertanya. Interaksi serta kolaborasi yang baik antara guru dan siswa dalam penerapan diyakini dapat berkontribusi secara positif terhadap peningkatan kemampuan berpikir kritis, membaca, menulis, meta kognisi, dan memecahkan masalah (Davoudi \& Sadeghi, 2015; Sun, 2012; Wahyudin \& Sukyadi, 2015). Komponen yang mempengaruhi manajemen kelas adalah regulasi, pengembangan sosial, dan pengembangan emosional. Situasi kelas yang gaduh, tidak aman, dan tidak tertib dapat mengganggu fokus belajar dan mengurangi motivasi belajar peserta didik. Kelas yang efektif merupakan kelas yang tertib serta mampu memfasilitasi kegiatan belajar, meningkatkan motivasi, serta memberikan rasa aman pada peserta didik. Hal ini berlaku secara umum dalam berbagai budaya, lokasi geografis, maupun jenjang pendidikan (Emmer \& Evertson, 2013; Morris et al., 2013). Cara yang dapat dilakukan guru untuk menciptakan iklim belajar yang kondusif, yaitu: meningkatkan kedisiplinan siswa, menciptakan komunitas yang saling peduli dan saling percaya; memaksimalkan penggunaan waktu dalam kegiatan belajar mengajar (Eggen \& Kauchak, 2016).

Hambatan berikutnya yaitu ketimpangan sarana dan prasarana. Dalam pengamatan yang dilakukan, beberapa sekolah yang diteliti ternyata masih mengalami kendala terkait dengan pemenuhan standar sarana dan prasarana sebagaimana diamanatkan dalam Permendiknas No. 24 tahun 2007 tentang Standar Sarana dan Prasarana untuk Sekolah Dasar, Sekolah Menengah Pertama, dan Sekolah Menengah Atas. Ketimpangan kualitas serta kuantitas sarana dan prasarana, juga masih terjadi di daerah-daerah. Ada beberapa sekolah di kawasan perdesaan, yang masih memiliki keterbatasan terkait dengan penyediaan sarana dan prasarana. Media pendidikan yang tersedia di sekolah, juga masih belum mencukupi. Ketimpangan pemenuhan standar sarana dan prasarana tidak hanya terjadi antara desa dan kota, melainkan juga antar sekolah di kawasan perkotaan dan antar sekolah di kawasan perdesaan. Tidak mengherankan jika implementasi kurikulum di sekolah-sekolah tidak sejalan dengan harapan yang diharapkan oleh para pembuat kebijakan (Febriana, Arlianty, Diniaty, \& Fauzi'ah, 2017).

Ketersediaan buku teks merupakan salah satu hal yang berpengaruh terhadap kegiatan pembelajaran. Revisi kurikulum dan transisi kebijakan seringkali berimplikasi negatif terhadap konten maupun pendistribusian buku teks. Pada tahun ajaran 2017/2018 misalnya, revisi terhadap standar isi mengharuskan dilakukannya perubahan pada sejumlah konten yang terdapat dalam buku teks. Akibatnya pendistribusian buku teks ke sekolah-sekolah menjadi terlambat. Sampai dengan awal bulan September 2017 seluruh sekolah yang diteliti masih belum mendapatkan buku guru maupun buku siswa. Sementara itu buku penunjang yang tersedia di sekolah tidak lagi selaras dengan materi kurikulum yang telah direvisi. Hambatan lain terkait dengan pelaksanaan aspek mencoba dalam penerapan saintifik inkuiri, yaitu: (1) minimnya sumber belajar yang tersedia (tidak seluruh sekolah memiliki sumber belajar yang memadai terkait dengan materi atau pokok bahasan tertentu); (2) kurangnya literasi informasi (tidak seluruh peserta didik memiliki kemampuan; alat, maupun sumber daya untuk dapat memperoleh informasi dari sumber lain); (3) keterbatasan akses internet (peserta didik tidak diberikan izin untuk membawa perangkat pintar ke sekolah, tidak seluruh sekolah memiliki laboratorium komputer, akses siswa terhadap internet di rumah masih cukup rendah).

Sebagian guru masih mengeluhkan ketersediaan waktu, minimnya bahan, dan keterbatasan biaya. Selain itu, sebagian besar guru masih belum mampu memanfaatkan potensi lokal. Faktor budaya dan ketimpangan

Jurnal Civics: Media Kajian Kewarganegaraan |169 
ekonomi juga menjadi salah satu hambatan dalam mendukung proses pelaksanaan kegiatan belajar mengajar di sekolah. Otonomi sekolah seharusnya dapat memberikan keleluasaan kepada tiap-tiap sekolah untuk dapat meningkatkan manajemen pengelolaan sekolah dengan berfokus pada kolaborasi antar sekolah dan antar berbagai pengambil kebijakan dalam komunitas lokal, walau masih terikat pada berbagai standar yang telah ditetapkan oleh pemerintah (Heffernan, 2018; Neeleman, 2019; Schleicher, 2012).

Dalam penerapan pendekatan saintifik, aspek menanya adalah aspek yang dirasa paling sulit untuk diterapkan. Banyak peserta didik yang memiliki antusiasme, rasa ingin tahu, serta motivasi yang rendah dalam mengikuti mata pelajaran PPKn. Bidang studi ini dianggap membosankan dan kurang memiliki manfaat terhadap kehidupan peserta didik.

Rendahnya kemampuan berpikir kritis, penyelesaian masalah, dan pengambilan keputusan juga menghambat proses pembelajaran (Fischer et al., 2012; Murawski, 2014; Wang \& Zheng, 2016). Untuk menjawab atau menanyakan pertanyaan tingkat tinggi, siswa harus memiliki kemampuan untuk melakukan analisis, mengevaluasi, menyintesis, dan mengaplikasikan apa yang telah diketahui. Rasa ingin tahu dan pemikiran kritis mutlak diperlukan dalam pengembangan aspek menanya (Chen, Hand, \& Norton-Meier, 2017; Kelley-Mudie \& Phillips, 2016; Leslie, 2014). Frekuensi pertanyaan, distribusi pertanyaan, pemberian respons, dan jeda waktu akan dapat meningkatkan efektivitas pertanyaan dalam aspek menanya (Eggen \& Kauchak, 2016). Tidak seluruh guru yang diteliti, memberikan insentif dan apresiasi terhadap inisiatif siswa untuk membuat atau menjawab pertanyaan. Pemberian pujian dan masukan dapat dilakukan untuk meningkatkan motivasi peserta didik (Baadte \& Schnotz, 2014; Burgers, Eden, Van Engelenburg, \& Buningh, 2015; Bushman, Moeller, \& Crocker, 2011).

Kemampuan komunikasi dan kolaborasi diperlukan untuk menciptakan pembelajaran yang aktif, inovatif, kreatif, dan menyenangkan. Sayangnya, belum seluruh guru maupun peserta didik memiliki kemampuan komunikasi dan kolaborasi yang baik. Kedua hal ini harus terus ditingkatkan untuk meningkatkan kualitas proses pembelajaran.

Rendahnya literasi dan minat baca siswa juga menjadi hambatan dalam penerapan aspek menanya. Siswa yang tidak terbiasa membaca akan sulit menemukan ide-ide penting dan mengintegrasikannya dalam sebuah pertanyaan. Salah satu hambatan dalam peningkatan minat baca siswa adalah kurangnya ketersediaan buku di sekolahsekolah. Rendahnya kemampuan literasi informasi juga mempengaruhi penerapan pendekatan saintifik. Dalam proses pembelajaran, guru masih mengalami beberapa hambatan seperti (1) kesulitan dalam memilih dan menggunakan media yang sesuai dengan peserta didik (2) kesulitan dalam menggunakan sumber pembelajaran yang sesuai, dan (3) kesulitan dalam menggunakan media alternatif.

Masalah lain yang ditemukan dalam penerapan pendekatan saintifik aspek mengamati adalah minimnya penggunaan teknologi informasi dan komunikasi (TIK) selama kegiatan belajar mengajar. Seluruh sekolah yang diteliti, masih melarang siswa untuk membawa ponsel pintar ke sekolah. Sedangkan akses internet di sekolah masih dipengaruhi oleh (1) koneksi jaringan yang buruk, (2) bandwidth, (3) gangguan teknis, (4) keterbatasan kemampuan TIK yang dimiliki operator sekolah. Akibatnya kegiatan belajar mengajar menjadi sangat tergantung dengan pemakaian buku teks.

Kendala dalam penerapan pendekatan saintifik salah satunya dikarenakan tidak seluruh komponen sekolah (kepala sekolah, guru, peserta didik, wali murid, dewan sekolah) terlibat dalam kerangka perubahan. Pergeseran paradigma dari pembelajaran tradisional ke pembelajaran berbasis pencarian hanya dapat dilaksanakan jika seluruh pihak terlibat dalam proses inkuiri (Dzhamalova, Timonin, Kolesov, Pavlov, \& Evstegneeva, 2016). Selain hambatan budaya dan nilai, keragaman bahasa, gender, dan 
status ekonomi juga bisa menjadi tantangan tersendiri (Eggen \& Kauchak, 2016). Oleh karena itu, pengembangan kompetensi pedagogik dan kompetensi profesional perlu terus dilakukan agar proses pembelajaran dapat dilakukan secara aktif, inovatif, kreatif, dan menyenangkan.

Keterbatasan pelatihan dan sosialisasi mengenai perencanaan, kegiatan belajar mengajar, evaluasi pembelajaran juga menjadi masalah tersendiri. Beberapa faktor yang menjadi penghambat dalam peningkatan profesionalisme guru adalah: (1) terjadi ketaksesuaian antara jadwal pengembangan profesional dengan jadwal mengajar, (2) tidak ada (jarang) dilakukan upaya pengembangan profesional guru, (3) tanggung jawab keluarga, (4) program pengembangan profesional yang bersifat mandiri, membutuhkan biaya yang cukup mahal, (5) kurangnya dukungan dari ekosistem pendidikan, (6) guru tidak merasa perlu melakukan perkembangan profesionalitas.

Sebagian besar guru yang diteliti, masih belum dapat merancang, melaksanakan, mengolah, melaporkan, dan memanfaatkan hasil penilaian dengan baik. Masalah yang dihadapi pendidik antara lain kesulitan dalam merumuskan indikator, menyusun butir-butir instrumen, dan melaksanakan penilaian sikap dengan menggunakan berbagai macam teknik penilaian autentik. Selain itu, banyak di antara pendidik yang merasa kurang percaya diri dalam melaksanakan penilaian keterampilan karena belum sepenuhnya memahami bagaimana menyusun instrumen dan rubrik penilaian keterampilan (Kemendikbud, 2016). Oleh karena itu, guru perlu terus dilatih untuk dapat merencanakan, melaksanakan, melaporkan, dan memanfaatkan hasil penilaian dengan baik.

Kesulitan lain yang banyak dikeluhkan pendidik berkaitan dengan penulisan deskripsi capaian aspek sikap, aspek pengetahuan, dan aspek keterampilan. Di samping itu sejumlah pendidik mengaku bahwa mereka belum percaya diri dalam mengembangkan butirbutir soal pengetahuan karena kurang memahami bagaimana untuk merumuskan indikator dan menyusun butir-butir soal untuk pengetahuan faktual, konseptual, dan prosedural yang dikombinasikan dengan keterampilan berpikir tingkat rendah hingga tinggi. Satuan pendidikan juga mengalami kesulitan dalam menentukan Kriteria Ketuntasan Minimal (KKM), merumuskan kriteria kenaikan kelas, dan kriteria kelulusan peserta didik. Permasalahan lain yang sering muncul adalah penetapan KKM, penentuan predikat dan deskripsi pada setiap Kompetensi Dasar (KD) sebagai kompetensi minimal untuk selanjutnya menjadi KKM mata pelajaran atau KKM satuan pendidikan. Satuan pendidikan juga mengalami kesulitan dalam menentukan kebijakan berkaitan dengan nilai hasil remedial.

Hanya 50\% dari guru yang diteliti telah membuat penilaian keterampilan. Adapun teknik yang digunakan guru dalam melakukan penilaian keterampilan adalah tes praktik dan tes proyek dengan menggunakan daftar cek atau skala penilaian (rating scale) yang dilengkapi rubrik. Seluruh guru PPKn yang diteliti sepakat bahwa teknik penilaian portofolio kurang tepat untuk diterapkan dalam mata pelajaran PPKn karena keterbatasan waktu yang tersedia untuk dapat melaksanakan eksperimen/eksplorasi secara kontinu. Dua orang guru yang telah membuat penilaian keterampilan, merupakan guru yang telah mendapatkan sosialisasi secara intensif dan menjadi instruktur nasional kurikulum 2013.

Walaupun setengah dari guru yang diteliti telah membuat format penilaian sikap, pengetahuan, dan keterampilan namun saat dilakukan observasi di kelas ternyata seluruh guru belum melakukan penilaian autentik secara utuh terutama yang berupa penilaian sikap dan keterampilan. Selama proses pembelajaran berlangsung guru disibukkan dengan berbagai aktivitas belajar mengajar seperti menjawab pertanyaan siswa, mengarahkan jalannya diskusi, membantu siswa yang kesulitan saat menggunakan peralatan komputer, menjaga iklim kelas agar selalu kondusif, serta menciptakan suasana belajar yang menyenangkan. Penilaian belum dilakukan secara utuh sesuai dengan prinsip sahih, objektif, adil, terpadu, terbuka, menyeluruh, berkesinambungan, sistematis, dan akuntabel. 
Rasio guru dan siswa hampir dua hingga tiga kali lipat lebih padat jika dibandingkan dengan rata-rata rasio guru dan siswa di negara-negara OECD. Rata-rata guru SMP yang diteliti harus mengurus 24 hingga 36 murid dalam satu kelas. Adapun rata-rata guru di negara-negara OECD hanya dibebani mengajar 13 murid dalam satu kelas (OECD, 2017). Wajar jika guru merasa kesulitan untuk dapat melakukan penilaian autentik sebagaimana yang diamanatkan dalam kurikulum.

Solusi yang dilakukan guru untuk mengatasi hambatan dalam pelaksanaan kurikulum adalah dengan mengikuti sosialisasi terkait dengan penerapan kurikulum 2013. Selain itu guru juga menghadiri berbagai seminar, pelatihan, dan kegiatan MGMP yang bertujuan untuk meningkatkan kompetensi dan profesionalitas guru. Di negara maju peningkatan kualitas pendidikan dilakukan dengan peningkatan standar pendidikan dan pengembangan kompetensi guru dan kepala sekolah (Robinson, 2011). Pengembangan profesional guru memiliki berbagai kegunaan, antara lain: (1) menambah kapasitas pengetahuan individu dalam mata pelajaran tertentu; (2) meningkatkan kemampuan individu dan perkembangan berbagai pendekatan, termasuk juga teknik mengajar dan perkembangan terbaru dalam dunia pendidikan; (3) memungkinkan guru untuk menerapkan perubahan dalam kurikulum atau berbagai aspek lain yang diperlukan untuk meningkatkan praktik belajar mengajar; (4) memungkinkan sekolah untuk mengembangkan dan mengaplikasikan strategi-strategi baru terkait dengan kurikulum atau praktik mengajar; (5) saling bertukar informasi dengan para ahli di bidangnya, (6) membantu guru yang lemah agar dapat menjadi lebih efektif (Schleicher, 2012).

Sekolah merupakan miniatur dari kehidupan masyarakat, dimana setiap komponennya terus menerus melakukan pencarian bentuk dan siap melakukan berbagai perubahan. Oleh karena itu, dalam reformasi kurikulum, seluruh komponen sekolah dituntut untuk melakukan berbagai perubahan, baik dari pola pikir, materi kurikulum, maupun proses pembelajaran. Untuk mendukung upaya reformasi dan mengatasi hambatan dalam pelaksanaan kurikulum, guru berupaya menjalin kerja sama yang baik dengan kepala sekolah, wakil kepala sekolah, dan rekan sejawat. Melalui proses pemberian umpan balik, diskusi, dan konsultasi secara berkelanjutan antara guru, kepala sekolah, wakil kepala sekolah, dan rekan sejawat, pemahaman guru mengenai praktik pembelajaran yang baik dan relevan, dapat terus dikembangkan. Selain itu, guru juga membangun hubungan kemitraan dengan wali murid sebagai bagian dari pengembangan kompetensi sosial mereka.

\section{Simpulan}

Berdasarkan paparan deskripsi hasil penelitian dan pembahasan, dapat ditarik kesimpulan sebagai berikut. Problematika guru dalam penerapan pendekatan saintifik, antara lain: (1) keterbatasan kompetensi guru; (2) ketimpangan sarana dan prasarana; (3) keterbatasan waktu dan biaya; (4) minimnya kreativitas dan inovasi; (5) kurangnya antusiasme, motivasi, dan rasa ingin tahu peserta didik; (6) rendahnya kemampuan berpikir kritis, penyelesaian masalah, dan pengambilan keputusan; (7) kurangnya kemampuan komunikasi dan kolaborasi; (8) rendahnya minat baca; (9) kurangnya literasi informasi; (10) rendahnya literasi teknologi informasi dan komunikasi (TIK); (11) keterbatasan pelatihan dan sosialisasi mengenai perencanaan, proses, maupun evaluasi pembelajaran. Solusi yang dilakukan guru untuk mengatasi hambatan dalam penerapan pendekatan saintifik dalam pembelajaran, antara lain: (1) mengikuti seminar, pelatihan, dan kegiatan MGMP; (2) menjalin kerja sama dengan kepala sekolah, waka kurikulum, dan rekan sejawat; serta (3) membangun hubungan kemitraan antara guru dengan wali murid. Adapun saran mengenai penerapan pendekatan saintifik dalam kurikulum, antara lain: (1) perlu dilakukan pengkajian kembali terhadap konsep pendekatan saintifik dalam pembelajaran, (2) perlunya dilakukan penelitian lebih lanjut mengenai rasio kelas yang ideal dalam 
penerapan pendekatan saintifik serta pembelajaran alternatif seperti apa yang efektif digunakan dalam kelas yang memiliki jumlah murid cukup banyak (overcrowded); (3) perlunya dilakukan peningkatan kompetensi guru, baik kompetensi pedagogik, kepribadian, sosial, dan profesional sehingga proses pembelajaran dapat berlangsung sesuai dengan harapan, (4) perlunya dilakukan pelatihan secara khusus dan intensif, terkait dengan kepemimpinan dan manajemen sekolah di tingkat satuan pendidikan, dan (5) peningkatan kualitas kepemimpinan atau manajemen sekolah perlu difokuskan pada upaya mendukung, mengevaluasi, dan mengembangkan kualitas guru, termasuk juga melakukan upaya koordinasi kurikulum, pelaksanaan berbagai program yang mendukung implementasi kurikulum, melakukan monitoring dan evaluasi praktik mengajar di sekolah, mempromosikan dilakukannya pengembangan profesionalitas guru, serta mendukung dilakukannya upayaupaya kolaboratif untuk melaksanakan kurikulum secara lebih baik.

\section{Referensi}

Baadte, C., \& Schnotz, W. (2014). Feedback effects on performance, motivation and mood: are they moderated by the learner's self-concept? Scandinavian Journal of Educational Research, 58(5), 570-591.

https://doi.org/10.1080/00313831.2013. 781059

Balser, T. J., Grabau, A. A., Kniess, D., \& Page, L. A. (2017). Collaboration and communication. New Directions for Institutional Research, 2017(175), 6579. https://doi.org/10.1002/ir.20236

Barron, B., \& Darling-Hammond, L. (2008). Teaching for meaningful learning: a review of research on inquiry-based and cooperative learning. Powerful Learning: What We Know About Teaching for Understanding. San Francisco, CA: John Wiley \& Sons Inc. https://doi.org/10.1207/S1532799XSSR 0501

Basrowi, \& Suwandi. (2008). Memahami penelitian kualitatif. Jakarta: Rineka Cipta.

Broome, E. (Ed.). (1973). Educating for the future: 21st century teaching. Nort Carolina: Division for Exceptional Children Department of Public Instruction.

Burgers, C., Eden, A., Van Engelenburg, M. D., \& Buningh, S. (2015). How feedback boosts motivation and play in a braintraining game. Computers in Human Behavior, 48, 94-103. https://doi.org/10.1016/j.chb.2015.01.03 8

Bushman, B. J., Moeller, S. J., \& Crocker, J. (2011). Sweets, sex, or self-esteem? Comparing the value of self-esteem boosts with other pleasant rewards. Journal of Personality, 79(5), 993-1012. https://doi.org/10.1111/j.14676494.2011.00712.x

Chen, Y. C., Hand, B., \& Norton-Meier, L. (2017). Teacher roles of questioning in early elementary science classrooms: a framework promoting student cognitive complexities in argumentation. Research in Science Education, 47(2), 373-405. https://doi.org/10.1007/s11165-0159506-6

Clarkeburn, H., \& Kettula, K. (2012). Fairness and using reflective journals in assessment. Teaching in Higher Education, 17(4), 439-452. https://doi.org/10.1080/13562517.2011. 641000

Cogan, J., \& Derricott, R. (Ed.). (1998). Citizenship for the 21st century: an international perspective on education. London: Kogan Page.

Davoudi, M., \& Sadeghi, N. A. (2015). A systematic review of research on questioning as a high-level cognitive strategy. English Language Teaching, $8(10)$, 76-90. https://doi.org/10.5539/elt.v8n10p76

Dede, C. (2010). Comparing frameworks for 21st century skills. In J. Bellanca \& R. 
Brandt (Ed.), 21st century skills: rethinking how students Learn (hal. 5176). Bloomington: Solution Tree Press.

Dzhamalova, B. B., Timonin, A. I., Kolesov, V. I., Pavlov, V. V., \& Evstegneeva, A. A. (2016). Consolidating orientation of pedagogic functions of university teachers in international students training. International Journal of Environmental and Science Education, 11(9), 3041-3051. https://doi.org/10.12973/ijese.2016.902a

Eggen, P. D., \& Kauchak, D. P. (2016). Educational psychology windows on classrooms (10th ed.). Pearson. https://doi.org/10.5840/schoolman19351 2221

Emmer, E. T., \& Evertson, C. M. (2013). Classroom management for middle and high school teachers (9th ed.). Boston: Allyn \& Bacon/Pearson.

Endersby, L., Phelps, K., \& Jenkins, D. (2017). The virtual table: a framework for online teamwork, collaboration, and communication. New directions for student leadership, 2017(153), 75-88. https://doi.org/10.1002/yd.20231

Febriana, B. W., Arlianty, W. N., Diniaty, A., \& Fauzi'ah, L. (2017). An analysis of curriculum implementation on high schools in Yogyakarta. AIP Conference Proceedings, 1911(December). https://doi.org/10.1063/1.5015995

Fischer, A., Greiff, S., \& Funke, J. (2012). The process of solving complex problems. The Journal of Problem Solving, 4(1). https://doi.org/10.7771/1932-6246.1118

Garcia, J. A., \& Lewis, T. E. (2014). Getting a grip on the classroom: from psychological to phenomenological curriculum development in teacher education programs. Curriculum Inquiry, 44(2), 141-168.

Goodlad, J. I. (1967). The future of learning and teaching. Washington: National Education Association.

Heffernan, A. (2018). Power and the 'autonomous' principal: autonomy, teacher development, and school leaders' work. Journal of Educational Administration and History, 50(4), 379396.

https://doi.org/10.1080/00220620.2018. 1518318

Johnson-Mardones, D. F. (2014). Toward a multidimensional concept of curriculum: understating curriculum as phenomenon, field and design. European Journal of Curriculum Studies, 1(2), 172-177.

Jonnaert, P., \& Therriault, G. (2013). Curricula and curricular analysis: some pointers for a debate. Prospects, 43(4), 397-417. https://doi.org/10.1007/s11125-0139285-7

Kelley-Mudie, S., \& Phillips, J. (2016). To build a better question. Feature, 44(5), 15-19.

Kemendikbud. (2013). Modul pelatihan kurikulum 2013. Jakarta: Badan Pengembangan Sumber Daya Manusia Pendidikan dan Kebudayaan dan Penjaminan Mutu Pendidikan.

Kemendikbud. (2016). Panduan penilaian oleh pendidik dan satuan pendidikan untuk sekolah menengah pertama. Jakarta: Direktorat Jenderal Pendidikan Dasar dan Menengah Kementerian Pendidikan dan Kebudayaan.

Kisfalvi, V., \& Oliver, D. (2015). Creating and maintaining a safe space in experiential learning. Journal of Management Education, 39(6), 713740. https://doi.org/10.1177/1052562915574 724

Kurniawan, I. S., \& Toharudin, U. (2017). Values of local wisdom: A potential to develop an assessment and remedial. International Journal of Evaluation and Research in Education (IJERE), 6(1), 71. https://doi.org/10.11591/ijere.v6i1.6349

Lederman, N. G. (2006). Syntax of nature of science within inquiry and science 
instruction. In L. Flick \& N. G. Lederman (Ed.), Scientific inquiry and nature of science (hal. 301-317). Chicago: Springer.

Leslie, I. (2014). Curious: The desire to know and why your future depends on it. Basic Books.

Morris, P., Lloyd, C. M., Millenky, M., Leacock, N., Raver, C. C., \& Bangser, M. (2013). Using classroom management to improve preschoolers ' social and emotional skills. Mdrc. MDRC.

Moyer, J. E. (1970). Bases for world understanding and cooperation. Suggestions for teaching the young child. Washington, D.C: Association for Supervision and Curriculum Development, NEA.

Mulyasa, E. (2013). Pengembangan dan implementasi kurikulum 2013. PT Remaja Rosdakarya.

Murawski, L. M. (2014). Critical thinking in the classroom... and beyond. Journal of Learning in Higher Education, 10(1), 25-30.

https://doi.org/10.1021/acs.jchemed.6b0 0406

Musingafi, M. C. C., Mhute, I., Zebron, S., \& Kaseke, K. E. (2015). Planning to teach: interrogating the link among the curricula, the syllabi, schemes and lesson plans in the teaching process. Journal of Education and Practice, 6(9), 54-59. D

Muth'im, A. (2014). Understanding and responding to the change of curriculum in the context of Indonesian education. American Journal of Educational Research, 2(11), 1094-1099. https://doi.org/10.12691/education-211-15

Neeleman, A. (2019). The scope of school autonomy in practice: an empirically based classification of school interventions. Journal of Educational Change, 20(1), 31-55. https://doi.org/10.1007/s10833-018-
9332-5

OECD. (2017). Education at a Glance 2017. OECD. https://doi.org/10.1787/eag2017-en

Pike, G. (2008). Global education. In J. Arthur, I. Davies, \& C. Hahn (Ed.), The SAGE handbook of education for citizenship and democracy. London: SAGE Publications Ltd. https://doi.org/10.4135/9781849200486

Rahmawati, A., Tairas, M. M. W., \& Nawangsari, N. A. F. (2018). Children's school readiness: teachers' and parents' perceptions. International Journal of Pedagogy and Teacher Education, 2(1), 9-20.

Robinson, K. (2011). Out of our minds: learning to be creative. Hoboken N.J.: Capstone.

Santrock, J. W. (2018). Educational Psychology (Sixth). New York: McGraw Hill Education.

Schleicher, A. (Ed.). (2012). Preparing teachers and developing school leaders for the 21st Ccntury. Lessons from around the world. OECD Publishing. https://doi.org/10.1787/9789264174559en

Schmidt, S. J. (2018). Creating a classroom culture built on community. Journal of Food Science Education, 17(1), 2-4. https://doi.org/10.1111/15414329.12133

Shane, H. G., \& Bernadine, T. H. (1981). Educating for a new millenium: visions of 132 scholars. Indiana: Phi Delta Kappa Educationa Foundation.

Sun, Z. (2012). An empirical study on new teacher-student relationship and questioning strategies in ESL classroom. English Language Teaching, 5(7), 175183. https://doi.org/10.5539/elt.v5n7p175

Suyanto, S. (2017). A reflection on the implementation of a new curriculum in Indonesia: A crucial problem on school 
readiness. AIP Conference Proceedings, 1868(August).

https://doi.org/10.1063/1.4995218

Tobiason, G., Heritage, M., Chang, S., Jones, B., \& Herman, J. (2014). Developing and refining lessons: planning learning and formative assessment for math college and career ready standards. California: The Regents of the University of California.

Wahyudin, A. Y., \& Sukyadi, D. (2015). phenomenon, field and design a closer look at the implementation of the curriculum 2013 in indonesia: should the scientific approach be used in EFL classroom? Rangsit Journal of Educational Studies, 2(2), 56-70. https://doi.org/10.14456/rjes.2015.11

Wang, X., \& Zheng, H. (2016). Reasoning critical thinking: is it born or made? Theory and Practice in Language Studies, $6(6), \quad 1323$. https://doi.org/10.17507/tpls.0606.25

Wanless, S. B. (2016). The Role of Psychological Safety in Human Development. Research in Human Development, 13(1), 6-14. https://doi.org/10.1080/15427609.2016. 1141283

Williams, J. H., \& Cummings, W. C. (2015). Education from the bottom up: UNICEF's education programme in Somalia. International Peacekeeping, 22(4), 419-434. https://doi.org/10.1080/13533312.2015. 1059284 